PROCEDIA

Studi Kasus dan Intervensi Psikologi ISSN:2302-1462; e-ISSN: 2722-7669

Volume 8(3) 112-118, September 2020

DOI: $10.22219 /$ procedia.v8i3.14303

\title{
Konseling Eksistensial Humanistik untuk mengurangi kecemasan terhadap masa depan
}

Diana Zumrotus Sa'adah, Universitas Muhammadiyah Malang, Malang, Indonesia

Korespondonesi:

Diana Zumrotus Sa'adah, email: saadahdiana@gmail.com

\begin{abstract}
Riwayat artike
Naskah diterima:

$22 / 06 / 2020$

Revisi diterima:

$15 / 07 / 2020$

Naskah disetujui:

$27 / 08 / 2020$
\end{abstract}

\begin{abstract}
Abstrak
Masa depan merupakan misteri bagi setiap orang, tidak ada yang mengetahui apa yang akan terjadi di masa depan. Dengan ketidakpastinnya tidak sedikit individu yang merasa cemas. Metode asesmen menggunakan wawancara, observasi, dan tes psikologi. Subjek seorang perempuan berusia 22 tahun dan mengalami kecemasan masa depan karena melakukan kesalahan yang dianggapnya tidak termaafkan oleh Tuhan. Intervensi menggunakan konseling eksistensial humanistik dengan tujuan untuk membantu subjek mengurangi kecemasan masa depannya. Hasil intervensi adanya penurunan skor kecemasan masa depan.

Kata kunci: konseling eksistensial humanistik, kecemasan, masa depan.
\end{abstract}

\section{Latar Belakang}

Spiritual berasal dari kata spirit yang berarti "semangat, jiwa, roh, sukma, mental, batin, rohani dan keagamaan". Spiritual dimaknai dengan asumsi mengenai nilai-nilai transcendental. Spiritualitas ialah merupakan sebagai pengalaman manusia secara umum dari suatu pengertian akan makna, tujuan dan moralitas (May, 1999).

Permasalahan spiritualitas berkaitan tentang dirinya dengan Tuhan atau nilai-nilai yang ada di budaya yang membuat beberapa individu merasakan gejala-gejala neurotik yang mengarah pada kecemasan (May, 1991). Kecemasan merupakan suatu keadaan dimana seseorang merasakan sensasi takut dengan makna yang kurang spesifik. Kecemasan biasanya ditandai oleh kekhawatiran tentang bahaya yang tidak terduga yang terletak di masa depan. Kecemasan merupakan keadaan emosional negatif yang ditandai dengan adanya firasat dan somatik ketegangan, seperti hati berdetak kencang, berkeringat, serta kesulitan bernapas (Holtum, 2014).

Perasaan ini merupakan ketidakberdayaan neurotik, rasa tidak aman, tidak matang, dan kekurangmampuan dalam menghadapi tuntutan realitas (lingkungan), kesulitan dan tekanan kehidupan sehari-hari. Perasaan cemas adalah bentuk ketidakberanian ditambah kerisauan 
terhadap hal-hal yang tidak jelas, merupakan takut yang tidak jelas objeknya dan tidak jelas pula alasannya. Kecemasan adalah suatu keadaan emosional yang mempunyai ciri yang mempunyai rangsangan terhadap fisiologis, perasaan tegang yang tidak menyenangkan, dan perasaan aprehensif bahwa sesuatu yang buruk akan terjadi (Nevid, 2005).

Banyak manusia yang mempertanyakan dirinya dan menyebabkan dirinya mengalami masalah spiritualitas berkaitan dengan nilai nilai yang ia anut dan juga pencarian yang ia lakukan dan menyebabkan individu itu mengalami kecemasan (May, 1999). Pada kasus ini subjek mengalami masalah yang berhubungan dengan adanya kecemasan terhadap masa depan, karena melakukan kesalahan dan merasa tidak termaafkan oleh Tuhan. Adapun penanganan menggunakan pendekatan eksistensial humanistik untuk pasien yang mengalamai permasalahan spiritualitas dengan fokus kecemasan terhadap masa depannya.

\section{Metode Asesmen}

Metode asesmen menggunakan wawancara, observasi, studi dokumentasi, tes intelegensi dan tes kepribadian. Jenis wawancara yang digunakan ialah wawancara klinis. Wawancara klinis digunakan sebagai metode untuk mengetahui apa yang sebenarnya dirasakan dan menjadi masalah subjek. Dalam melakukan wawancara menggunakan kriteria diagnostik DSM-V sebagai pedoman wawancara untuk memudahkan dan memfokuskan pertanyaan yang diutarakan pada subjek. Observasi digunakan untuk melihat perilaku-perilaku yang muncul yang bisa mengarah pada suatu gangguan atau masalah, dan juga dapat menjadi data penunjang dari hasil wawancara. Pedoman observasi disusun berdasarkan kriteria diagnostik DSM-V.

Selain itu, asesmen menggunakan Weschler Adult Intellegence Scale (WAIS) untuk mengetahui kapasitas intelektual guna memprediksi seberapa jauh pemahaman subjek terhadap intervensi yang diberikan, dan melihat patologis yang ada pada diri subjek. Beberapa tes kepribadian juga digunakan, yaitu tes grafis digunakan untuk mengungkap kepribadian dan konsep diri subjek secara mendalam. Tes grafis yang diberikan adalah Draw A Person (DAP) dan BAUM.

\section{Presentasi Kasus}

Subjek merupakan mahasiswa semester lima di salah satu Universitas swasta di Kota Malang. Subjek mengeluh kebingungan dengan apa yang terjadi padanya, Ia sering mengurung diri selama berhari-hari dan sering bermimpi buruk terhadap siksaan yang pahit jika meninggal sehingga membuatnya menarik diri dari lingkungan. Subjek juga mudah marah jika ada kebisingan yang terjadi di sekitarnya. Subjek memiliki hubungan yang kurang harmonis dengan ayahnya, dan juga tidak terlalu dekat dengan ibunya. Sewaktu kecil (Sekolah Dasar), subjek sering dibentak oleh ayahnya ketika melakukan kesalahan, hal ini membuat subjek menjadi takut dengan ayahnya hingga dewasa. Subjek mengaku bahwa dirinya jarang bercerita pada siapa pun di rumah.

Beberapa bulan yang lalu, subjek mengaku merasakan kehampaan dalam hidupnya. Subjek merasa tidak memiliki semangat dalam hidup, sehingga mengakibatkan dirinya memakai narkoba yang diberikan oleh temannya. Selama sebulan memakai narkoba, subjek pernah bermimpi disiksa di kubur. Semenjak itu subjek berhenti menggunakan narkoba dan menjalani keseharian seperti sedia kala. Beberapa minggu setelahnya, subjek mengaku sering bermimpi buruk dan menjadi sangat takut dengan konsekuensi yang akan di dapat. Subjek takut ketika meninggal dunia dirinya belum siap dan belum bertaubat. Ketakutan tersebut membuatnya mengurung diri selama beberapa hari dikamar.

Menurut pandangan eksistensial humanistik, yang diungkapkan oleh Rollo May bahwa individu $\mathrm{n}$ mengalami gejala patologis ketika tidak mampu bebas menjadi dirinya sendiri, dimana individu tersebut tersesat dalam penghayatannya, tidak mampu menghayati masa depan 
(May, 2019). Terdapat dua bentuk kebebasan dalam individu, yang pertama adalah kebebasan eksistensial, yang kedua kebebasan esensial. Kebebasan eksistensial adalah kebebasan untuk melakukan sesuatu berdasarkan pilihan-pilihan yang dibuatnya saat ini. Sedangkan kebebasan esensial merupakan kebebasan atas sesuatu yang terjadi. Hasil asesmen menunjukkan bahwa subjek sudah menghentikan perilaku penggunaan narkobanya, namun masih tetap memikirkan masa lalu yang dianggap sebagai suatu kesalahan, dimana seharusnya subjek dapat fokus untuk memberbaiki diri bukan pada kesalahan masa lalu.

Takdir menurut May bukan berarti sesuatu yang sudah diatur atau ditetapkan. Takdir adalah destinasi manusia, terminus, dan tujuan. Takdir tidak bisa dihapus, namum dapat memilih bagaimana cara merespons, bagaimana akan hidup dari talenta-talenta dalam diri sendiri yang tidak bertentangan atau membuat tertekan (May, 1991). Subjek merasa tertekan dengan identitasnya sebagai pengguna narkoba yang dianggap sebagai bentuk kegagalan mencapai eksistensi individu, padahal seharusnya subjek bisa merespon hal itu dengan lebih logis karena subjek sudah berhenti menggunakan narkoba.

Rollo May mengungkapkan bahwa individu yang mengalami ketakutan mengenai dirinya saat ini dikarenakan Ia mengalami kekosongan, kesepian, kecemasan, kebersalahan, diomonic, dan will yang belum tercapai. Kekosongan adalah ketika individu tidak mampu memahami kenapa suatu perilaku yang Ia lakukan terjadi; kesepian merupakan perasaan keterasingan sebagai akibat dari kegagalan dalam berinterasi; kecemasan yaitu seseorang merasa terancam dengan keberadaannya, sedangkan kebersalahan yaitu perasaan gagal, atau ketidakmampuan dalam memenuhi eksistensi dirinya, diomonic dan will yang belum tercapai merupakan bagaimana ia belum mampu mencapai hal-hal yang Ia inginkan dalam perjalanan hidup (May, 2019). Subjek menarik diri dari lingkungan, merasakan keterasingan merupakan konsep patologis dari eksistensial humanistik.

Teori dari Rollo May memberikan penjelasan mengenai kecemasan subjek terhadap masa depannya. Eksistensinya merasa terancam dengan hal-hal yang belum terjadi seperti siksa neraka, atau perasaan mengecewakan orang terdekat karena agama Islam melarang pemakaian narkoba. Subjek merasa terancam apakah orang-orang yang disayangi akan meninggalkannya ketika mengetahui Ia pernah menggunakan narkoba karena itu barang haram. Hal ini menjadi fokus dari intervensi yang diberikan kepada subjek, memberikan pemahaman bahwa Ia masih memiliki hal positif di dalam dirinya yang akan memberikan pengaruh pada penerimaan diri, dan masa lalu, fokus pada diri yang lebih positif. (May, 2019).

Subjek cenderung sulit mempelajari hal-hal yang baru, namun subjek mampu jika diajarkan secara perlahan meskipun motivasi untuk berprestasi rendah dan kurang mampu mempelajari hal yang bersifat abstrak. Kepribadian diri subjek yang introvet, sensitif, egois, dan agresif membuatnya semakin merasakan takut, cemas, dan tidak mampu. Ketidakmampuan subjek untuk menyesuaikan diri di lingkungan sosial membuatnya mengalami hambatan dalam melakukan hubungan sosial yang semakin membuatnya merasa tidak aman dan cenderung menghindari permasalahan yang dialami karena adanya perasaan tidak mampu dan harga diri yang rendah.

Ada beberapa konsep dasar yang digunakan Rollo May dalam menjelaskan kepribadian individu, yang pertama adalah secara sadar sepenuhnya/being in the world (May, 1953). Ada beberapa konsep patologis ketika; (1) seseorang mengalami keterpisahan dari lingkungan, (2) mengalami kekurangan hubungan antar pribadi yang bermakna, dan (3) ketersaingan dari diri yang autentik. Konsep kedua yaitu minwelt atau hubungan kita dengan orang lain, artinya sebagai manusia yang bersosial hendaknya harus berhubungan dengan orang lain sebagai manusia, bukan sebagai benda (May, 1953). Konsep ketiga yaitu eigenwelt yang mengacu pada hubungan seseorang dengan dirinya sendiri. Subjek mengalami kendala dalam dirinya/eigenwelt dan eksistensi hubungannya dengan orang lain/minwelt yang merupakan bentuk ketakutan 
untuk mengecewakan orang tersayang, dan juga mengenai dirinya yang telah melakukan kesalahan yang tidak termaafkan (May, 1953).

Berdasarkan hasil pemeriksaan psikologi yang telah dilakukan diperoleh skor IQ sebesar 125 yang berarti subjek memiliki tingkat kecerdasan pada taraf superior dan terdapat perbedaan yang signifikan antara sub-verbal dan performance, hal ini mengindikasikan subjek memiliki kapasitas intelektual yang baik namun tidak diiringi dengan usaha yang sesuai. Keseluruhan profil inteligensi yang dimilikinya memiliki kelebihan pada daya ingat (ingatan jangka pendek dan panjang), dan kemampuan verbal, minat terhadap lingkungan sosial dan konsentrasi cukup baik serta tidak mudah stres. Namun subjek memiliki ide yang cukup terbatas pada perencanaan, konsentrasi yang mudah terganggu, cenderung tergesa-gesa dan kurang berhati-hati dalam mengamati maupun mempersepsikan sesuatu, mengintegrasikan visual. Subjek juga memiliki permasalahan pada menjaga hubungan dengan orang lain, kurang bersahabat / tidak ramah dengan lingkungan, kurang bisa menilai, dan cenderung impulsive.

Subjek memiliki kemampuan matematika yang rendah, kurang mampu memecahkan masalah, berpikir abstrak, kurang minat dalam membaca, dan kurang fleksibel dalam berpikir. Namun hal tersebut dapat diimbangi oleh kemampuan kapasitas visual yang sangat baik yang berhubungan dengan belajar, serta organisasi visual motor yang baik dan dalam konsep visual. Subjek merupakan individu yang tertutup dan mengatakan sering sedih karena pemaknaannya bahwa ia telah melakukan kesalahan yang tidak termaafkan oleh Tuhan dan subjek menjadi takut mati dalam keadaan buruk.

Konsep kematian juga dibahas sebagai alasan seseorang mengalami perasaan cemas atau tidak (biasa) dengan nonbeing, kesadaran pada individu membawanya pada kesadaran akan sesuatu yang menakutkan. Kematian merupakan hal yang ditakutkan. Rasa takut pada kematian atau ketakutan terhadap konsekuensi akan sesuatu yang akan didapatkan setelah kematian juga termasuk dalam konsep nonbeing dari Rollo May (May, 1950). Subjek mengalami ketakutan akan konsekuensi dari perbuatannya sebagai orang yang pernah menggunakan narkoba, subjek mengalami ketakutan yang mendalam terhadap konsep azab, jika dikaitkan dengan teori eksistensial dari Rollo May, subjek memiliki permasalahan dalam dimensi nonbeing (May, 1950).

Kecemasan subjek yang lainnya juga terhadap keberadaan dirinya sebagai pecandu narkoba juga berkaitan dengan konsep Rollo May mengenai kecemasan. Kecemasan normal menurut Rollo May diidentifikasikan sebagai sebagai sesuatu yang proporsional bagi ancaman, tidak melibatkan represi, dan bisa ditentang secara konstruktif ditingkatan sadar (May, 1950). Sedangkan, kecemasan neurotik diidentifikasikan sebagai reaksi tidak proporsional terhadap ancaman, melibatkan represi, dan bentuk-bentuk konflik intrapsikis lainnya, dan diatur oleh beragam jenis pemblokiran aktivitas dan kesadaran. Jika dikaitkan dengan subjek, kecemasan neurotik berkaitan dengan masalah kecemasan tentang hal-hal yang belum terjadi yang menjadi sumber patologis (Schneider, 1999). Gejala-gejala dari hasil asesmen bahwa subjek telah mengurung dirinya berhari-hari atas ketakutannya terhadap konsekuensi atas perbuatan di masa lalu merupakan bentuk kecemasan mengenai masalah kecemasannya terhadap masa depan.

\section{Diagnosis dan Prognosis}

\section{Diagnosis}

Diagnosis Hasil asesmen yang dilakukan dan berdasarkan rujukan dari Diagnostic and Statistical Manual of Mental Disorder Fifth Editionn (DSM-V), maka ditegakkan diagnosis bahwa subjek mengalami permasalahan kecemasan terhadap masa depan. Subjek merasakan cemas, firasat buruk, tidur tidak tenang, mudah menangis, gangguan tidur, sering terbangun malam hari, sering mimpi buruk, perasaan depresi, kehilangan minat, sedih, bangun dini hari, berkurangnya kesenangan pada hobi. Subjek juga mengalami perasaan yang berubah-ubah sepanjang hari 
dalam sebulan terakhir dan sering tiba tiba berkeringat dingin, namun subjek masih mampu untuk melakukan aktifitas sehari-hari.

\section{Prognosis}

Berdasarkan hasil asesmen psikologi yang telah dilakukan terkait dengan potensi dan kelebihan subjek, maka dapat diprediksikan prognosis subjek terhadap hasil intervensi adalah positif. Hal ini dikarenakan subjek memiliki komitmen yang kuat untuk menjadi lebih baik dari keadaan sebelumnya. Kemampuan kognitif superior yang dimiliki oleh subjek juga diharapkan mampu membuat subjek memahami prosedur dan pelaksanaan intervensi yang diberikan dengan baik.

\section{Intervensi}

Intervensi yang diberikan dalam kasus ini adalah konseling eksistensial, terdapat asumsi bahwa individu bebas dan oleh karenanya bertanggung jawab atas pilihan yang diambil dan perbuatan yang dilakukan. Pandangan eksistensial didasarkan pada model pertumbuhan dan mengkonsepkan kesehatan bukan keadaan sakit (Smith, 2018). Subjek memiliki pemaknaan eksistensi diri dan orang lain yang rendah sehingga mengakibatkan adanya ketakutan yang berlebihan terhadap masa depan. Terapi ini membantu subjek untuk mengubah sudut pandangnya dan melihat kedaan tersebut menjadi lebih logis. Terapi eksistensial tidak dirancang untuk menyembuhkan seperti tradisi model medis, subjek tidak dipandang sebagai orang yang sedang sakit melainkan sebagai orang yang merasa bosan atau kikuk dalam menjalani kehidupan.

Terapi eksistensial humanistik tidak memiliki teknik-teknik yang ditentukan secara ketat dan posedur-prosedur terapi diambil dari beberapa teori terapi lainnya seperti teori Gestalt dan Analisis Transaksional (Corey, 2007). Intervensi dapat diakhiri jika subjek telah mampu untuk mengimplementasikan kesadaran tentang dirinya dan mengarahkan diri untuk mencapai hidup yang lebih bermakna. Kondisi ini memungkinkan subjek menemukan jalan mudah untuk mengaktualisasikan diri.

Teknik utama eksistensial humanistik pada dasarnya adalah penggunaan pribadi terapis dan hubungan terapis-subjek sebagai kondisi perubahan. Namun eksistensial humanistik juga merekomendasikan beberapa teknik khusus seperti menghayati keberadaan dunia obyektif dan subyektif subjek, pengalaman pertumbuhan simbolik yaitu suatu bentuk interpretasi dan pengakuan dasar tentang dimensi-dimensi simbolik dari pengalaman yang mengarahkan pada kesadaran yang lebih tinggi, pengungkapan makna, dan pertumbuhan pribadi (Smith, 2018).

Proses intervensi psikologi dengan menggunakan konseling eksistensial humanistik yang dilaksanakan terdiri dari tiga tahap berikut.

1. Tahap pertama, konselor membantu klien dalam mengidentifikasi dan mengklarifikasi asumsi mereka terhadap dunia. Klien diajak mendefinisikan cara pandang agar eksistensi mereka diterima. Konselor mengajarkan mereka bercermin pada eksistensi mereka dan meneliti peran mereka dalam hal penciptaan masalah dalam kehidupan mereka.

2. Pada tahap kedua, klien didorong agar bersemangat untuk lebih dalam meneliti sumber dan otoritas dari system mereka. Semangat ini akan memberikan klien pemahaman baru dan restrukturisasi nilai dan sikap mereka untuk mencapai kehidupan yang lebih baik dan dianggap pantas.

3. Tahap ketiga berfokus pada untuk bisa melaksanakan apa yang telah mereka pelajari tentang diri mereka. Klien didorong untuk mengaplikasikan nilai barunya dengan jalan yang kongkrit. Klien biasanya akan menemukan kekuatan untuk menjalani eksistensi kehidupanya yang memiliki tujuan. 


\section{Hasil dan Pembahasan}

\section{Hasil}

Hasil intervensi menunjukkan bahwa subjek merasa lebih tenang, mengakui apa yang terjadi pada dirinya sebagai individu yang pernah menggunakan narkoba, masih merasa inferior dan belum bisa untuk memaksa dirinya diterima orang-orang disekitarnya. Subjek mengungkapkan bahwa setelah proses intervensi memiliki keberanian untuk menyampaikan kepada ibunya bahwa ia pernah menggunakan narkoba namun sudah berhenti. Subjek meminta maaf pada ibunya, dan ternyata ibunya menangis tersedu dan tidak marah. Ibu subjek menyampaikan agar subjek jangan menyalahkan Tuhan, tetap jaga ibadah agar Tuhan senantiasa mengampuni. Selain itu, setelah proses intervensi subjek juga mengaku mulai mengetahui bahwa dirinya punya kelebihan dan saat ini lebih baik untuk berfokus pada hal yang menjadi kelebihannya agar menjadi manusia yang lebih produktif. Subjek mulai menyibukkan diri lagi sebagai mahasiswa. Perubahan sebelum dan setelah intervensi berdasarkan pada aspek-aspek kecemasan dapat dilihat pada Tabel 1

\section{Pembahasan}

Konseling eksistensial humanistik membantu klien dalam pemaknaan mengenai diri sendiri dan permasalahan mengenai eksistensi dirinya dengan orang lain dan nilai-nilai spiritualitas atau ketuhanan yang ada dalam dirinya sehingga ketika individu tidak mampu memaknainya akan memunculkan permasalahan-permasalahan dan bahkan sampai gangguan atau patologis.

Ada beberapa konsep patologis ketika seseorang mengalami keterpisahan dari lingkungan, mengalami kekurangan hubungan antar pribadi yang bermakna, dan ketersaingan dari diri yang autentik. Hubungan individu dengan individu yang lain juga sangat penting, karena sebagai manusia sosial hendaknya harus berhubungan dengan orang lain sebagai manusia bukan sebagai benda.

Dalam kasus yang terjadi pada klien mengalami kendala dalam dirinya dan eksistensi hubungan nya dengan orang lain. Bentuk ketakutan untuk mengecewakan orang tersayang, dianalisis sebagai bentuk permasalahan eksistensial dengan orang lain. Dalam eksistensial humanistik pribadi yang sehat adalah yang mampu memaknai secara utuh dirinya saat ini. Hal itu diperoleh dari proses pemaknaan-pemaknaan yang dilakukan klien (Schneider, 1999).

Selama proses intervensi subjek termasuk pribadi yang kooperatif sehingga dengan cepat dapat memahami bahwa ia sedang tidak baik-baik saja dalam memaknai dirinya dan selama proses penanganan termasuk cepat dalam memaknai dirinyat. Subjek juga mengaku bahwa

Tabel 1. Perubahan kecemasan subjek

\begin{tabular}{|c|c|c|}
\hline $\begin{array}{l}\text { Aspek } \\
\text { kecemasan }\end{array}$ & Sebelum intervensi & Setelah intervensi \\
\hline Fisik & $\begin{array}{l}\text { Keringat dingin } \quad \text { ketika } \\
\text { memikirkan masa depan, } \\
\text { selalu insomnia dan tidak bisa } \\
\text { tidur. }\end{array}$ & $\begin{array}{l}\text { Mulai tenang dan tidak insomnia dan } \\
\text { bisa tidur teratur. Ketika mengingat } \\
\text { masa depan merasa tidak takut lagi }\end{array}$ \\
\hline Afeksi/Emosional & $\begin{array}{l}\text { Panik ketika mengingat masa } \\
\text { depan }\end{array}$ & $\begin{array}{l}\text { Mulai tenang dan tau bahwa masih } \\
\text { ada waktu memperbaiki diri }\end{array}$ \\
\hline Kognitif & $\begin{array}{l}\text { Beranggapan bahwa dirinya } \\
\text { tidak akan mampu memperbaiki } \\
\text { masa depannya }\end{array}$ & $\begin{array}{l}\text { Mulai meyakini bahwa jika setiap } \\
\text { hari subjek bangun maka sata itu } \\
\text { ada kesempatan dari Tuhan untuk } \\
\text { dirinya memperbaiki diri }\end{array}$ \\
\hline
\end{tabular}


saat SMP dan SMA telah belajar ilmu tasawuf, didukung dengan taraf kecerdasan yang tergolong superior dan dorongan yang kuat untuk memahami diri membuatnya lebih cepat dalam menemukan makna-makna dari masalah yang sedang dialaminya.

Ketika subjek diajak untuk memahami bahwa pengguna narkoba dilarang agama, dan tidak diterima oleh pemerintah serta masyararakat. Subjek memahami konsep itu, karena pemahaman itu subjek jadi lebih mudah diajak memahami bahwa saat ini yang perlu dilakukan adalah menerima bahwa dirinya pernah melakukan kesalahan di masa lalu, namun subjek masih memiliki kesempatan untuk memperbaiki diri dan mengakui bahwa apa yang dialaminya saat ini adalah ujian serta kedepan akan berubah dan mnejadi lebih baik dari sebelumnya.

\section{Simpulan}

Konseling eksistensial humanistik dapat membantu subjek dalam pemaknaan mengenai diri sendiri dan permasalahan mengenai eksistensinya dengan orang lain serta kecemasan terhadap masa depannya. Subjek mampu memberikan pemaknaan terhadap masalahnya sehingga dapat lebih tenang dan sekarang dapat memahami dirinya serta menjalankan aktivitasnya sebagai mahasiswa.

\section{Referensi}

Alwisol. (2009). Psikologi kepribadian. Malang: UMM Press

American Psychiatric Association. (2005). Diagnostic and statistical manual of mental disorders fourth edition text revision. Washington DC.

Balán, I. C., Lejuez, C. W., Hoffer, M., \& Blanco, C. (2016). Anxiety for humanistic., 23(2), 205-220.

Cuijpers, P., van Straten, A., \& Warmerdam, L. (2007). Clinical Intervention A meta-analysis. Clinical Psychology Review, 27(3), 318-326. https://doi.org/10.1016/j.cpr.2006.11.001

Kendall, P. C. (Ed.). (2006). Child and adolescent therapy : Clinical treatment for anxiety procedures (3rd ed). New York: Guilford Press.

Nelson-Jones, R. (2015). Teori dan praktik konseling dan terapi. Yogyakarta: Pustaka Pelajar

Putranto, A.K. (2016). Eksistensial humanistik dalam intervensi klinis. Jakarta 